\title{
Structure and genetic relationships between Brazilian naturalized and exotic purebred goat domestic goat (Capra hircus) breeds based on microsatellites
}

\author{
Joelliton Domingos de Oliveira ${ }^{1,2}$, Maria Luiza Silveira de Paiva Igarashi ${ }^{1,3}$, \\ Théa Mírian Medeiros Machado ${ }^{4}$, Marcos Mateo Miretti ${ }^{3 *}$, Jesus Aparecido Ferro ${ }^{3}$ \\ and Eucleia Primo Betioli Contel ${ }^{1}$ \\ ${ }^{1}$ Departamento de Genética, Faculdade de Medicina, Universidade de São Paulo, Ribeirão Preto, \\ SP, Brazil. \\ ${ }^{2}$ Universidade Estadual do Mato Grosso do Sul, Dourados, MS, Brazil. \\ ${ }^{3}$ Departamento de Tecnologia, Faculdade de Ciências Agrárias e Veterinária, \\ Universidade Estadual Paulista, Jaboticabal, SP, Brazil. \\ ${ }^{4}$ Departamento de Zootecnia, Universidade Federal de Viçosa, Viçosa, MG, Brazil.
}

\begin{abstract}
The genetic relationships and structure of fourteen goat (Capra hircus) populations were estimated based on genotyping data from 14 goat populations ( $n=410$ goats) at 13 microsatellite loci. We used analysis of molecular variance (AMOVA), principal component analysis (PCA) and $F$ statistics $\left(F_{I S}, F_{I T}\right.$ and $F_{S T}$ ) to evaluate the genetic diversity ( $H o$, $\mathrm{He}$ and $\mathrm{ad}$ ) of the goats. Genetic distances between the 14 goat populations were calculated from allelic frequency data for the 13 microsatellite markers. Moderate differentiation was observed for the populations of the undefined breeds (including the Anglo-Nubian-M breed), the naturalized Brazilian breeds (Moxotó, Canindé), the exotic purebred breeds (Alpine, Saanen, Toggenbourg and Anglo-Nubian) and the naturalized Brazilian Graúna group. Our AMOVA showed that a major portion (88.51\%) of the total genetic variation resulted from differences between individual goats within populations, while between-populations variation accounted for the remaining $11.49 \%$ of genetic variation. We used a Reynolds genetic distance matrix and PCA to produce a phenogram based on the 14 goat populations and found three clusters, or groups, consisting of the goats belonging to the undefined breed, the naturalized breeds and the exotic purebred breeds. The closer proximity of the Canindé breed from the Brazilian state of Paraíba to the Graúna breed from the same state than to the genetically conserved Canindé breed from the Brazilian state of Ceará, as well as the heterozygosity values and significant deviations from Hardy-Weinberg equilibrium suggests that there was a high number of homozygotes in the populations studied, and indicates the importance of the State for the conservation of the local breeds. Cataloguing the genetic profile of Brazilian goat populations provides essential information for conservation and genetic improvements programs.
\end{abstract}

Key words: goat, microsatellite, genetic distance, PCA, AMOVA, genetic relationships, genetic diversity, F statistics.

Received: April 7, 2006; Accepted: September 28, 2006.

\section{Introduction}

Microsatellite polymorphisms have proved to be a useful tool for the analysis of genetic structure and the genetic divergence between populations and is also important for verifying pedigree relationships and providing fundamental information for the preservation of breeds.

Compared with other farm animals, few studies have been conducted using microsatellite markers to investigate genetic distance in domesticated goats(Capra hircus)

Send correspondence to Joelliton Domingos de Oliveira. Departamento de Genética, Faculdade de Medicina, Ribeirão Preto, SP, Brazil. E-mail: oliveira.jd@ig.com.br.

*Present address: Wellcome Trust Sanger Institute, Hinxton, Cambridge, United Kingdom CB10 1SA.
(Saitbekova et al., 1999; Yang et al., 1999; Barker et al. 2001; Kim et al., 2002 ; Li et al., 2002; Baumung et al., 2004). In Brazil, caprine breeds have been studied using morphological characters (Machado et al., 2000), protein markers (Igarashi et al., 2000) and random amplified polymorphic DNA (RAPD) markers (Oliveira et al., 2005).

According to the Brazilian Geographic and Statistics Foundation (Instituto Brasileiro de Geografia e Estatística -IBGE), the vast majority of Brazilian goats (93\%) are located in the northeastern region of Brazil where two groups can be identified, naturalized goats and goats of undefined breed. The naturalized goats tend to be small and highly heterogeneous, especially for coat colors. There are four major breeds, Moxotó, Canindé, Repartida and Marota, along with the Graúna group formed by goats with black 
coat color (Santos, 1987) but which has not yet been regarded as a Brazilian breed by the Brazilian Goat Breeders Association (Associação Brasileira de Criadores de Caprinos $-\mathrm{ABCC}$ ) because this association requires other standardized characteristics in addition to coat color. The goats of undefined breed (UDB) constitute the largest group in the Brazilian northeast, and includes all goats that cannot be assigned to any other breed. This group comprises goats with diverse coat color patterns as well as various degrees of crossing with exotic purebred goats such as those of the Toggenbourg, Anglo-Nubian, Alpine and Saanen breeds, such crossings having been made to improve milk and meat production (KP Pant, personal communication). The crossing of diverse breads interferes with genetic conservation programs for naturalized and UDB breeds and affects the genetic structure and relationships among the breeds. Assessing the genetic composition of Brazilian naturalized, UDB and exotic purebred goats is important for determining the current genetic structure of these populations and would provide substantial information for genetic improvement and conservation programs. The objective of the present study was to investigate the genetic structures of 14 goat populations and to analyze the genetic relationship between them using 13 microsatellite markers. We included the Graúna group in our investigation to compare our results with those reported by Igarashi et al. (2000). To increase the understanding about the diversity of these goat populations we also compared our results to those of Araújo et al (2006) who also used microsatellite loci to investigate the genetic diversity between Alpine, Saanen and Moxotó goats.

\section{Material and Methods}

\section{DNA extraction and amplification conditions}

A total of 410 goats (Capra hircus) from a blood sample collection previously obtained by Igarashi et al. (2000) was used (Table 1).

We extracted DNA from $300 \mu \mathrm{L}$ of goat blood according to the method of Higuchi (1989) with some modifications. Amplification reactions were done in a TGradient (Biometra, Germany) thermocycler in a final reaction volume of $15 \mu \mathrm{L}$ containing $0.2-0.5 \mu \mathrm{g}$ of template DNA, $0.1 \mathrm{mM}$ of each dNTP, $0.5 \mathrm{U}$ of Taq DNA polymerase (Life Technologies, EUA), $1 \mathrm{X}$ reaction buffer $(50 \mathrm{mM} \mathrm{KCl}, 2 \mathrm{mM} \mathrm{MgCl} 2,20 \mathrm{mM}$ Tris-HCl, $\mathrm{pH}$ 8.4) and 10 pmol of primers. A two-stage touchdown amplification program was designed for DNA amplification. An initial denaturation step of $4 \mathrm{~min}$ at $94{ }^{\circ} \mathrm{C}$ was used in all programs, followed by amplification cycles in which the annealing temperature $(\mathrm{Tm})$ was gradually decreased by $1{ }^{\circ} \mathrm{C}$ every amplification cycle. This treatment was followed by a second stage consisting of either 28 or $30 \mathrm{am}$ plification cycles, in which the Tm remained constant. Denaturation and elongation steps were held constant for
Table 1 - List of the goat populations studied.

\begin{tabular}{|c|c|c|c|}
\hline Breed, cross or group & $\begin{array}{l}\text { Population } \\
\text { code }\end{array}$ & $\begin{array}{l}\text { Number of } \\
\text { animals }\end{array}$ & $\begin{array}{l}\text { State hosting } \\
\text { the population }\end{array}$ \\
\hline \multicolumn{4}{|l|}{ Exotic purebreds } \\
\hline $\begin{array}{l}\text { Alpine and German } \\
\text { Alpine }^{1}\end{array}$ & ALP & 119 & Minas Gerais \\
\hline Anglo-Nubian & AGN-P & 16 & Minas Gerais \\
\hline Saanen & SAA & 35 & Minas Gerais \\
\hline Toggenbourg & TOG & 28 & Minas Gerais \\
\hline \multicolumn{4}{|l|}{$\begin{array}{l}\text { Brazilian naturalized } \\
\text { breed }\end{array}$} \\
\hline Canindé & CAN-PB & 19 & Paraíba \\
\hline Canindé & CAN-CE & 24 & Ceará \\
\hline Canindé & CAN-RN & 29 & $\begin{array}{l}\text { Rio Grande do } \\
\text { Norte }\end{array}$ \\
\hline Moxotó & MOX-PB & 8 & Paraíba \\
\hline Moxotó & MOX-CE & 23 & Ceará \\
\hline \multicolumn{4}{|l|}{ Undefined breeds } \\
\hline Undefined breed & UDB-NE & 19 & $\begin{array}{l}\text { Ceará, north- } \\
\text { eastern }\end{array}$ \\
\hline undefined breed & UDB-CL & 16 & $\begin{array}{l}\text { Ceará, mid- } \\
\text { dle-eastern }\end{array}$ \\
\hline undefined breed & UDB-S & 20 & $\begin{array}{l}\text { Ceará, south- } \\
\text { ern }\end{array}$ \\
\hline \multicolumn{4}{|l|}{ Crossbred goats } \\
\hline Anglo-Nubian crossbred & AGN-M & 43 & Ceará \\
\hline \multicolumn{4}{|l|}{$\begin{array}{l}\text { Not yet recognized as a } \\
\text { Brazilian breed }\end{array}$} \\
\hline Graúna group & GRA-PB & 11 & Paraíba \\
\hline
\end{tabular}

${ }^{1}$ German Alpine and the Alpine breed animals were grouped together due to their small sample size.

$45 \mathrm{~s}$ at $94{ }^{\circ} \mathrm{C}$ and $72{ }^{\circ} \mathrm{C}$, respectively, during both stages. An elongation step of $10 \mathrm{~min}$ at $72^{\circ} \mathrm{C}$ was performed in all programs after stage 2 . The 13 microsatellite markers selected for assessing genetic diversity in the goat populations described in Table 1 were: INRA011, INRA040, BM3517, ILST030, ILST028, UWCA46, TEXAN02, ILST011, INRA023, SRCRSP9, MHCIIDR, INRA006 and IDVGA37. These markers were originally described in cattle, with the exception of the caprine SRCRSP9 markers. One PCR primer from each pair was labeled with an appropriate dye, 6FAM, HEX or NED (PE Biosystems, USA) and the polymerase chain reactions (PCR) were carried out as described above resulting in strong and specific PCR products which were analyzed in an ABI PRISM 377 automatic DNA sequencer using standard loading conditions and a $2 \mathrm{~h}$ electrophoresis run on $5 \%(\mathrm{w} / \mathrm{v})$ Long Ranger gel. Alleles were sized relative to a ROX GS 500 internal size standard (Applied Biosystems, USA) and analyzed with the Applied Biosystems GENESCAN program version 2.1. Size estimates, in base pairs (bp), were manually checked for genotyping errors. 


\section{Data analysis}

Allelic frequencies, observed heterozygosity $(\mathrm{Ho})$, expected heterozygosity $(\mathrm{He})$ and exact tests of genotypic frequencies for deviation from Hardy-Weinberg equilibrium (HWE) were carried out using the GENEPOP v.3.4 program (Raymond and Rousset, 1995). The exact test of Hardy-Weinberg proportion for multiple alleles (Guo and Thompson, 1992) was performed using the Markov chain procedure (1,000 batches, 5,000 iterations, 10,000 de-memorization steps). The number of private alleles and allelic diversity were assessed using the FSTAT program v.2.9.3 (Goudet, 2001). A principal component analysis (PCA) was performed on the populations using the PCAGEN program (J.Goudet, unpublished). Populations were ordered according to the first and second PCA axes. The significance of each principal component was assessed from 5,000 randomizations. The F-Statistics (Wright, 1951) were calculated by the method of Weir and Cockerham (1984) using the GDA program (Lewis and Zaykin, 1997) and the significance of the $\mathrm{F}$ values were estimated from 10,000 replicates by bootstrapping, with confidence intervals not including zero being considered significantly different from zero.

The groups obtained from the PCA analyses were subjected to analysis of molecular variance (AMOVA; Excoffier et al., 1992) using the ARLEQUIN 3.0 program (Excoffier et al., 2005). Significance was determined from 10,000 permutations. Reynolds distances (Reynolds et al., 1983 ) between populations were generated from allelic frequency data using the PHYLIP package, v.3.65 (Felsenstein, 2005). Genetic distances were calculated using the GENDIST program and used to construct a NeighborJoining (NJ) tree in the NEIGHBOR program. To test the robustness of tree topologies, 1,000 bootstrap replicates of the allele frequency file were generated in the SEQBOOT program and analyzed using GENDIST. Tree topologies were created for all replicates using NEIGHBOR and a consensus tree was generated by the CONSENSE program. These programs are incorporated in the PHYLIP package, v.3.65 (Felsenstein, 2005).

\section{Results}

\section{Genetic diversity within and between populations}

All 13 loci were polymorphic, showing an average of 15.6 alleles per locus $(\min =9, \max =26$ alleles; Table 2$)$. Allelic diversity was lowest for the MOX-PB (4.5) population and highest for ALP (12.8) population. The mean Ho value varied from 0.28 to 0.46 and $\mathrm{He}$ from 0.64 to 0.80 . The MOX-PB population was the least variable $(H e=0.64)$, while the ALP $(H e=0.80)$ and TOG $(H e=0.79)$ populations showing the highest $H e$ values. In a total of 203 alleles we detected 10 private alleles $(5 \%)$ over all the populations (Table 2 ) and the average private allele frequency was $0.075(\min =0.004, \max =0.0425)$.
We detected 38 non-significant deviations from HWE from a total of 182 loci/population ( $p>0.01)$. In contrast, the remaining loci/populations (144) showed Hardy-Weinberg disequilibrium ( $<<0.01$; Table 2$)$. The populations presenting loci with no significant deviations were: MOX-C (UWCA46, TEXAN02); MOX-PB (INRA040, BM3517, ILST030, UWCA46, TEXAN02, ILST011, INRA023, SRCRSP9, MHCIIR); CAN-CE (ILST028, TEXAN02); GRA-PB (ILST028, ILST011, INRA023, IDVGA37); AGN-M (ILST011, INRA023); AGN-P (BM3517, TEXAN02); TOG (BM3517, ILST028, ILST011， INRA023); SAA (BM3517, ILST011); UDB-NE (BM3517, ILST028, ILST011); UDB-CL (ILST028, TEXAN02, INRA023, IDVGA37); UDB-S (ILST028, TEXAN02, ILST011, INRA023). When either all populations or all loci were pooled, significant differences between $\mathrm{Ho}$ and $\mathrm{He}(\mathrm{p}<0.001)$ were detected (Table 2). Allele frequencies are available as supplementary material (Table S1).

\section{Genetic differentiation and PCA}

The pattern of genetic differentiation was represented by a plot of scores based on allelic frequency from 14 goat populations (Figure 1). The first principal component axis (PC1) accounted for $32.72 \%(\mathrm{p}=0.000)$ of the total genetic diversity, and the second (PC2), for $13.72 \%(p=0.056$, not significant). The PCA plot gives the position of the populations according to either their known or apparent origins (historical data; Igarashi et al., 2000). The PC1 axis represents the differentiation between exotic purebred populations (AGN-P, SAA, TOG and ALP) and native and UDB populations (MOX-CE, MOX-PB, CAN-CE, CAN-RN, CAN-PB, GRA-PB, AGN-M, UDB-NE, UDB-CL and UDB-S) whereas the PC2 axis, although not significant, apparently distinguishes native and UDB populations. From this, a primary structuring suggested three major groupings of populations: (1) AGN-P, SAA, TOG and ALP, (2) MOX-CE, MOX-PB, CAN-CE, CAN-RN, CAN-PB and GRA-PB, and (3) AGN-M, UDB-NE, UDB-CL and UDB-S.

\section{Genetic relationship}

The neighbor-joining phenogram (Saitou and Nei, 1987) based on genetic distance of Reynolds (1983), divided the populations into three branches similar to the historical data: (1) AGN-M, AGN-P, TOG, SAA and ALP, (2) MOX-CE, MOX-PB, CAN-CE, CAN-RN, CAN-PB and GRA-PB, and (3) UDB-NE, UDB-CL and UDB-S (Figure 2). The most consistent groupings were: UDB-S and UDB-CL (99\%); ALP and SAA, TOG, and AGN-P (95\%); and GRA-PB and CAN-PB (91\%). The detected groupings were as expected and consistent with the historical data of the origin of these populations and breeds. These groupings confirm the PCA primary structuring, except for the position of the AGN-M population. 
Table 2 - Summary of observed $(\mathrm{Ho})$, expected $(\mathrm{He})$, mean $(\mathrm{H})$ heterozygosity, allelic diversity $(\mathrm{ad})$ and number of private alleles $(\mathrm{pa})$ over all goat populations. At the single-population single-locus levels a total of 38 non-significant deviations from HWE were detected. Significant deviations from HWE were detected when either all populations or all loci were pooled $(\mathrm{p}<0.001) .{ }^{*}=$ no significant difference between $\mathrm{Ho}$ e $\mathrm{He}(\mathrm{p}>0.01)$.

\begin{tabular}{|c|c|c|c|c|c|c|c|c|c|c|c|c|c|c|c|}
\hline \multirow[t]{2}{*}{ Lócus } & \multirow{2}{*}{$\begin{array}{l}\mathrm{N} \text { of } \\
\text { alleles }\end{array}$} & \multirow{2}{*}{$\begin{array}{c}\text { Size } \\
\text { range }\end{array}$} & \multicolumn{2}{|c|}{ MOX-CE $(n=23)^{a}$} & \multicolumn{2}{|c|}{ MOX-PB $(\mathrm{n}=8)$} & \multicolumn{2}{|c|}{ CAN-CE $(n=24)$} & \multicolumn{2}{|c|}{ CAN-RN $(\mathrm{n}=29)$} & \multicolumn{2}{|c|}{ CAN-PB $(n=19)$} & GRA-PB $(\mathrm{n}=11)$ & AGN-1 & $n=43)$ \\
\hline & & & Ho & $\mathrm{He}$ & Ho & $H$ & Ho & $\mathrm{He}$ & Ho & $\mathrm{He}$ & Ho & $\mathrm{He}$ & Ho & Ho & $\mathrm{He}$ \\
\hline INRA011 & 26 & $196-250$ & 0.22 & 0.73 & 0.00 & 0. & 0.13 & 0.63 & 0.17 & 0.82 & 0.21 & 0.74 & 0.82 & 0.26 & 0.59 \\
\hline & & & & & & & & & & & $(0.00$ & & $(0.000)$ & & \\
\hline INRA040 & 25 & $166-258$ & 0.17 & 0.80 & 0.50 & 0. & 0.26 & 0.79 & 0.41 & 0.81 & 0.31 & 0.82 & 0.27 & 0.26 & 0.83 \\
\hline & & & & & & & & & & & $(0.00$ & & $(0.000)$ & & \\
\hline BM3517 & 14 & $100-138$ & 0.45 & 0.82 & 0.50 & 0. & 0.57 & 0.79 & 0.35 & 0.88 & 0.43 & 0.89 & $0.33 \quad 0.82$ & 0.47 & 0.74 \\
\hline & & & & & $(0.3$ & & & & & & $(0.00$ & & $(0.001)$ & & \\
\hline ILST030 & 14 & $142-181$ & 0.22 & 0.79 & 0.38 & 0. & 0.38 & 0.83 & 0.43 & 0.82 & 0.32 & 0.81 & 0.73 & 0.58 & 0.82 \\
\hline & & & & & & & & & & & $(0.00$ & & $(0.000)$ & & \\
\hline ILST028 & 14 & $111-164$ & 0.35 & 0.57 & 0.25 & 0. & 0.58 & 0.53 & 0.45 & 0.73 & 0.31 & 0.75 & 0.50 & 0.51 & 0.72 \\
\hline & & & & & & & & & & & $(0.00$ & & $(0.232)^{*}$ & & \\
\hline UWCA46 & 17 & $97-140$ & 0.52 & 0.55 & 0.50 & 0. & 0.42 & 0.87 & 0.11 & 0.76 & 0.29 & 0.85 & 0.76 & 0.40 & 0.74 \\
\hline & & & & & & & & & & & $(0.00$ & & $(0.000)$ & & \\
\hline TEXAN02 & 9 & $105-133$ & 0.09 & 0.12 & 0.50 & 0. & 0.21 & 0.26 & 0.28 & 0.62 & 0.37 & 0.74 & 0.27 & 0.30 & 0.61 \\
\hline & & & & & & & & & & & $(0.00$ & & $(0.009)$ & & \\
\hline ILST011 & 9 & $262-284$ & 0.18 & 0.64 & 0.50 & 0. & 0.33 & 0.57 & 0.46 & 0.69 & 0.35 & 0.68 & 0.72 & 0.74 & 0.67 \\
\hline & & & & & & & & & & & $(0.00$ & & $(0.027)^{*}$ & & \\
\hline INRA023 & 12 & $191-217$ & 0.13 & 0.49 & 0.38 & 0. & 0.17 & 0.31 & 0.32 & 0.74 & 0.37 & 0.68 & 0.74 & 0.60 & 0.74 \\
\hline & & & & & & & & & & & $(0.00$ & & $(0.011)^{*}$ & & \\
\hline SRCRSP9 & 18 & $106-137$ & 0.52 & 0.79 & 0.88 & 0. & 0.54 & 0.85 & 0.59 & 0.84 & 0.37 & 0.81 & $0.55 \quad 0.82$ & 0.23 & 0.75 \\
\hline & & & & & & & & & & & $(0.00$ & & $(0.001)$ & & \\
\hline MHCIIR & 14 & $193-228$ & 0.39 & 0.81 & 0.25 & 0. & 0.21 & 0.80 & 0.22 & 0.82 & 0.13 & 0.78 & 0.09 & 0.23 & 0.80 \\
\hline & & & & & & & & & & & $(0.00$ & & $(0.000)$ & & \\
\hline INRA006 & 19 & $95-137$ & 0.30 & 0.78 & 0.25 & 0. & 0.58 & 0.89 & 0.59 & 0.82 & 0.39 & 0.67 & 0.45 & 0.51 & 0.77 \\
\hline & & & & & & & & & & & $(0.00$ & & $(0.001)$ & & \\
\hline IDVGA37 & 12 & $192-216$ & 0.57 & 0.78 & 0.25 & 0. & 0.38 & 0.86 & 0.52 & 0.85 & 0.53 & 0.82 & 0.73 & 0.51 & 0.75 \\
\hline & & & & & & & & & & & $(0.00$ & & $(0.131)^{*}$ & & \\
\hline Mean H & 15.6 & & 0.32 & 0.67 & 0.39 & 0. & 0.37 & 0.69 & 0.38 & 0.78 & 0.34 & 0.77 & 0.34 & 0.43 & 0.73 \\
\hline & & & & & & & & & & & $(0.00$ & & $(0.000)$ & & \\
\hline$a d$ & & & 7.1 & & 4.5 & & 7.9 & & 9.0 & & 7.8 & & 7.1 & 9.3 & \\
\hline$p a$ & & & 2 & & 0 & & 1 & & 0 & & 1 & & 1 & 0 & \\
\hline Locus & ALP & $1=119)$ & & $\mathrm{P}(\mathrm{n}=16)$ & & TOC & $=28)$ & SAA & $=35$ ) & UDB- & $E(n=19)$ & UDB- & 3-CL (n = 16) & UDB-S & $=20)$ \\
\hline & Ho & $\mathrm{He}$ & $H$ & $\mathrm{He}$ & & Ho & $\mathrm{He}$ & Ho & $\mathrm{He}$ & Но & $\mathrm{He}$ & Но & $\mathrm{He}$ & Ho & $\mathrm{He}$ \\
\hline INRA011 & 0.39 & 0.91 & 0. & 0.85 & & 36 & 0.92 & 0.49 & 0.90 & 0.53 & 0.86 & 0.19 & 0.83 & 0.42 & 0.84 \\
\hline & & 000) & & $0.000)$ & & & & & & & .000) & & $(0.000)$ & $(0.0$ & \\
\hline INRA040 & 0.29 & 0.92 & 0. & 0.89 & & 43 & 0.90 & 0.51 & 0.89 & 0.44 & 0.88 & 0.44 & 0.89 & 0.47 & 0.91 \\
\hline & & 000) & & $0.000)$ & & & & & & & .000) & & $(0.000)$ & $(0.0$ & \\
\hline BM3517 & 0.48 & 0.76 & 0. & 0.57 & & .79 & 0.86 & 0.58 & 0.69 & 0.41 & 0.74 & 0.13 & 0.71 & 0.35 & 0.81 \\
\hline & & 000) & & $.056)^{*}$ & & & & & & & $011)^{*}$ & & $(0.000)$ & $(0.0$ & \\
\hline ILST030 & 0.22 & 0.79 & 0. & 0.74 & & 43 & 0.71 & 0.23 & 0.80 & 0.05 & 0.82 & 0.06 & 0.83 & 0.37 & 0.87 \\
\hline & & 000) & & .009) & & & & & & & .000) & & $(0.000)$ & $(0.0$ & \\
\hline ILST028 & 0.66 & 0.87 & 0. & 0.71 & & 64 & 0.79 & 0.51 & 0.83 & 0.41 & 0.48 & 0.50 & 0.68 & 0.50 & 0.56 \\
\hline & & 000) & & .003) & & & & & & & 070)* & & $(0.044)^{*}$ & $(0.11$ & \\
\hline UWCA46 & 0.43 & 0.75 & 0. & 0.72 & & .29 & 0.78 & 0.60 & 0.84 & 0.41 & 0.79 & 0.44 & 0.81 & 0.42 & 0.74 \\
\hline & & 000) & & .001) & & & & & & & .000) & & $(0.000)$ & $(0.0$ & \\
\hline TEXAN02 & 0.36 & 0.74 & 0. & 0.65 & & .11 & 0.60 & 0.17 & 0.62 & 0.37 & 0.55 & 0.19 & 0.38 & 0.26 & 0.31 \\
\hline & & 000) & & $.045)^{*}$ & & & & & & & .004) & & $(0.025)^{*}$ & $(0.03$ & \\
\hline ILST011 & 0.61 & 0.74 & 0. & 0.61 & & 68 & 0.73 & 0.49 & 0.66 & 0.36 & 0.60 & 0.33 & 0.59 & 0.71 & 0.66 \\
\hline & & 000) & & .004) & & & & & & & 053)* & & $(0.001)$ & $(1.0 c$ & * \\
\hline INRA023 & 0.42 & 0.77 & 0. & 0.82 & & .79 & 0.84 & 0.57 & 0.77 & 0.25 & 0.62 & 0.17 & 0.15 & 0.00 & 0.10 \\
\hline & & 000) & & .009) & & & & & & & .000) & & $(1.000)^{*}$ & $(0.02$ & \\
\hline SRCRSP9 & 0.42 & 0.86 & 0. & 0.68 & & 39 & 0.82 & 0.60 & 0.88 & 0.39 & 0.83 & 0.25 & 0.76 & 0.55 & 0.76 \\
\hline & & 000) & & .002) & & & & & & & .000) & & $(0.000)$ & $(0.0$ & \\
\hline MHCIIR & 0.09 & 0.60 & 0. & 0.64 & & 18 & 0.74 & 0.26 & 0.60 & 0.11 & 0.64 & 0.07 & 0.79 & 0.11 & 0.53 \\
\hline & & 000) & & $.000)$ & & & & & & & .000) & & $(0.000)$ & $(0.0$ & \\
\hline INRA006 & 0.26 & 0.87 & 0. & 0.79 & & 32 & 0.83 & 0.20 & 0.83 & 0.42 & 0.76 & 0.06 & 0.83 & 0.35 & 0.84 \\
\hline & & 000) & & $.000)$ & & & & & & & .000) & & $(0.000)$ & $(0.0$ & \\
\hline IDVGA37 & 0.54 & 0.83 & 0. & 0.77 & & .54 & 0.79 & 0.66 & 0.80 & 0.32 & 0.83 & 0.81 & 0.82 & 0.75 & 0.78 \\
\hline & & 000) & & $.000)$ & & & & & & & .000) & & $(0.071)^{*}$ & $(0.0$ & \\
\hline Mean H & 0.40 & 0.80 & 0. & 0.73 & & 46 & 0.79 & 0.45 & 0.78 & 0.34 & 0.72 & 0.28 & 0.70 & 0.40 & 0.67 \\
\hline & & 000) & & $.000)$ & & & & & & & $.000)$ & & $(0.000)$ & $(0.0$ & \\
\hline$a d$ & 12.8 & & 7. & & & .5 & & 9.3 & & 7.3 & & 6.8 & & 7.5 & \\
\hline$p a$ & 5 & & 0 & & & 0 & & 0 & & 0 & & 0 & & 0 & \\
\hline
\end{tabular}


We verified the undefined position of AGN-M and confirmed it similarity to the UDB goats by calculating the $\mathrm{F}_{\text {ST }}$ values from AGN-M grouped with either the UDB goats or the exotic purebreds. In the first case, the $\mathrm{F}_{\text {ST }}$ value was lower and significant (unpublished data), so we grouped the AGN-M population with the UDB goats for the $\mathrm{F}$-statistics analysis. The $\mathrm{F}$-values $\left(\mathrm{F}_{\mathrm{IS}}\right.$ and $\left.\mathrm{F}_{\mathrm{ST}}\right)$ were significant for all populations and groupings (UDB, native and exotic breeds; $p<0.01$ ) and the $F_{I S}$ values were high and

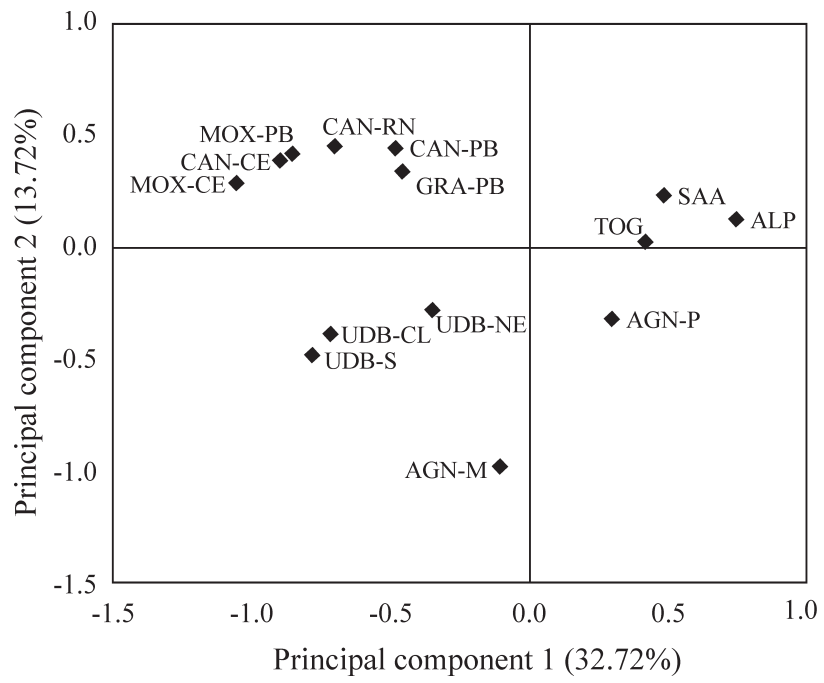

Figure 1 - Plot of scores of principal component analysis based on allele frequency of 14 populations of goats. 1: Moxotó Ceará (MOX-C); 2: Moxotó Paraíba (MOX-PB); 3: Canindé Ceará (CAN-CE); 4: Canindé Rio Grande do Norte (CAN-RN); 5: Canindé Paraíba (CAN-PB); 6: Graúna Paraíba (GRA-PB); 7: In absorbent crossing with Anglo-Nubian purebred (AGN-M); 8: Alpine and German Alpine (ALP); 9: Anglo-Nubian (AGN-P); 10: Toggenbourg (TOG); 11: Saanen (SAA): 12: northeastern undefined breed (UDB-NE); 13: middle-eastern undefined breed (UDB-CL); 14: southern undefined breed (UDB-S). positive for all the populations while the $\mathrm{F}_{\mathrm{ST}}$ value (0.105) was moderate (Table 3 ). When the F-values were estimated by grouping according to historical data, the values did not change considerably, the $\mathrm{F}_{\mathrm{IS}}$ mean values being high and

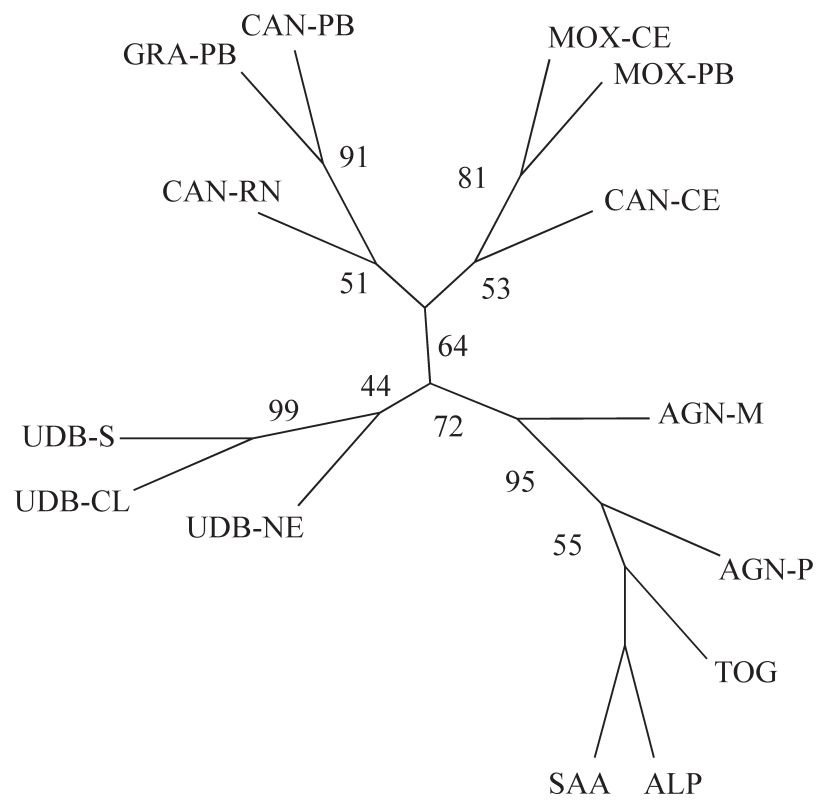

Figure 2 - Phenogram showing the relashionship among 14 Brazilian goat populations using genetic distance of Reynolds based on 13 microsatellites loci and Neighbor-Joining method (Saitou and Nei, 1987). Numbers at nodes are the percentages of 1,000 bootstrap replicates in which these nodes appeared. This is an unrooted tree. 1: Moxotó Ceará (MOX-C); 2: Moxotó Paraíba (MOX-PB); 3: Canindé Ceará (CAN-CE); 4: Canindé Rio Grande do Norte (CAN-RN); 5: Canindé Paraíba (CAN-PB); 6: Graúna Paraíba (GRA-PB); 7: In absorbent crossing with Anglo-Nubian purebred (AGN-M); 8: Alpine and German Alpine (ALP); 9: AngloNubian (AGN-P); 10: Toggenbourg (TOG); 11: Saanen (SAA): 12: northeastern undefined breed (UDB-NE); 13: middle-eastern undefined breed (UDB-CL); 14: southern undefined breed (UDB-S).

Table 3 - Estimates of $\mathrm{F}_{\mathrm{IS}}$ and $\mathrm{F}_{\mathrm{ST}}$ calculated by method of Weir and Cockerham (1984) based on allelic frequency of 14 goat populations, using the GDA program.

\begin{tabular}{lcccccccc}
\hline Locus & Only UDB & $\begin{array}{c}\text { Only native } \\
\mathrm{F}_{\text {IS }}\end{array}$ & $\begin{array}{c}\text { Only exotic } \\
\text { purebred } \mathrm{F}_{\text {IS }}\end{array}$ & $\begin{array}{c}\mathrm{F}_{\text {IS }} \text { to all the } \\
\text { populations }\end{array}$ & $\begin{array}{c}\text { Only UDB } \\
\mathrm{F}_{\text {ST }}\end{array}$ & $\begin{array}{c}\text { Only native } \\
\mathrm{F}_{\text {ST }}\end{array}$ & $\begin{array}{c}\text { Only exotic } \\
\text { purebred } \mathrm{F}_{\text {ST }}\end{array}$ & $\begin{array}{c}\mathrm{F}_{\text {ST }} \text { to all the } \\
\text { populations }\end{array}$ \\
\hline INRA011 & 0.567 & 0.778 & 0.555 & 0.620 & 0.112 & 0.033 & 0.031 & 0.110 \\
INRA040 & 0.590 & 0.632 & 0.602 & 0.611 & 0.023 & 0.003 & 0.022 & 0.040 \\
BM3517 & 0.515 & 0.480 & 0.288 & 0.401 & 0.044 & 0.013 & 0.107 & 0.095 \\
ILST030 & 0.592 & 0.619 & 0.647 & 0.639 & 0.051 & 0.039 & 0.074 & 0.085 \\
ILST028 & 0.258 & 0.350 & 0.262 & 0.288 & 0.054 & 0.243 & 0.054 & 0.152 \\
UWCA46 & 0.477 & 0.597 & 0.433 & 0.491 & 0.115 & 0.154 & 0.080 & 0.147 \\
TEXAN02 & 0.443 & 0.479 & 0.568 & 0.535 & 0.075 & 0.206 & 0.052 & 0.142 \\
ILST011 & 0.083 & 0.468 & 0.211 & 0.239 & 0.096 & 0.061 & 0.048 & 0.115 \\
INRA023 & 0.316 & 0.524 & 0.352 & 0.395 & 0.179 & 0.052 & 0.053 & 0.125 \\
SRCRSP9 & 0.584 & 0.364 & 0.481 & 0.471 & 0.048 & 0.074 & 0.080 & 0.075 \\
MHCIIDR & 0.790 & 0.719 & 0.796 & 0.765 & 0.121 & 0.044 & 0.197 & 0.130 \\
INRA006 & 0.525 & 0.444 & 0.714 & 0.587 & 0.073 & 0.078 & 0.067 & 0.093 \\
IDVGA37 & 0.287 & 0.413 & 0.281 & 0.339 & 0.053 & 0.041 & 0.047 & 0.073 \\
All loci & 0.476 & 0.531 & 0.475 & 0.494 & 0.078 & 0.079 & 0.069 & 0.105 \\
\hline
\end{tabular}


positive while the $\mathrm{F}_{\mathrm{ST}}$ mean values were moderate (Table 3).

The AMOVA results for the goat populations without any structuring revealed that most of the total variation occurred within populations ( $88.51 \%$; Table 4$)$. The remainder variation $(11.49 \%)$ was significantly different from zero $\left(\mathrm{F}_{\mathrm{ST}}=0.1149 ; \mathrm{p}<0.01\right)$ and resulted from differences among populations. When populations were structured according to historical data, most of the total variation was observed within populations (87.34\%). The remaining percentages of variation $(4.82 \%$ and $7.84 \%$ ) were significantly different from zero and were attributed to differences among groups $\left(\mathrm{F}_{\mathrm{CT}}=0.0482 ; \mathrm{p}<0.01\right)$ and among populations within groups $\left(\mathrm{F}_{\mathrm{SC}}=0.0824 ; \mathrm{p}<0.01\right)$ respectively (Table 4).

\section{Discussion}

Heterozygosity values and significant deviations from HWE suggest a large number of homozygotes in the populations studied. Deviations from HWE at microsatellites loci have been reported in various studies and indicate departure from random mating (Luikart et al.; 1999; Laval et al., 2000; Barker et al., 2001). This deviation might be the result of inbreeding, but could also have been caused by the presence of null or non-amplified alleles, allele grouping defects, a sampling structure effect or selection against heterozygotes. Araújo et al. (2006) used the INRA006 and ILST011 markers to study the Alpine, Saanen and Moxotó breeds but did not detect any deviations from HWE. This fact could be due to differences in the frequency, number and type of alleles founded in the two investigations, possibly due to a sampling effect. Comparing the remaining loci for the same populations, most of the loci revealed no heterozygote deficit or excess in the study of Araújo et al. (2006) but our data indicated a deficit of heterozygotes. We believe that this divergence could have occurred because the remaining loci compared for the same breeds were different in the two studies, suggesting that the choice of different loci can produce different results.

Populations were subjected to PCA for primary structuring, which resulted in a pattern of three major groups
(Figure 1), which is consistent with historical data and the neighbor-joining phenogram. This structuring is comparable to that reported by Igarashi et al. (2000) when the same populations were studied with protein markers.

The F-statistics analysis was performed based on established structuring from both analyses and historical data. The $\mathrm{F}_{\text {IS }}$ statistic is a measure of the extent of genetic inbreeding within subpopulations and can range from -1.0 (all individuals heterozygous) to +1.0 (no observed heterozygotes), while $\mathrm{F}_{\mathrm{IT}}$ is a measure of the mean reduction in heterozygosity of an individual relative to the total population (Wright, 1951; Weir and Cockerham, 1984). The $\mathrm{F}_{\mathrm{IS}}$ values detected for either all the populations or for the three groups (UDB, naturalized and exotic purebred) ranged from 0.475 to 0.531 and were high and significant $(\mathrm{p}<0.01)$. This indicates an excess of homozygotes due to a high level of inbreeding in the populations. However, Araújo et al. (2006) reported a different $\mathrm{F}_{\mathrm{IS}}$ value (0.0252) when they assessed the Alpine, Saanen and Moxotó breeds. This divergence in results may be understood if we consider that most of the loci analyzed in the two investigations were different.

The $\mathrm{F}_{\mathrm{ST}}$ value measures the degree of genetic differentiation between populations. Considering the interpretation of $\mathrm{F}_{\mathrm{ST}}$, it can be presumed that a value lying in the range 0 to 0.05 indicates little genetic differentiation, 0.05 to 0.15 indicates moderate differentiation, 0.15 to $0.25 \mathrm{a}$ large degree of differentiation and values above 0.25 very great differentiation (Wright 1978; Hartl and Clark, 1997). The $\mathrm{F}_{\mathrm{ST}}$ values identified for either all the populations or for the three groups fell in the range 0.05 to 0.15 , indicating moderate genetic differentiation for both conditions. The $\mathrm{F}_{\mathrm{ST}}$ value of 0.105 for all populations indicates that $10.5 \%$ of the total variability resulted from genetic differences between the populations while the remaining $89.5 \%$ was due to the high diversity between individuals within each population.

The AMOVA results without subgroups definition, or when considered a hierarchical structure, revealed genetic differentiation between the 14 populations. When the populations were unstructured the AMOVA $\mathrm{F}_{\mathrm{SC}}$ value was 0.1149 (Table 4 ), indicating that $11.49 \%$ of the total varia-

Table 4 - AMOVA results for 14 populations of goats based on $\mathrm{F}_{\text {ST }}$ pairwise distance values using ARLEQUIN program. Populations were assigned according to historical data into three groups: (1) AGN-P, SAA, TOG and ALP; (2) MOX-CE, MOX-PB, CAN-CE, CAN-RN, CAN-PB and GRA-PB; (3) AGN-M, UDB-NE, UDB-CL and UDB-S.

\begin{tabular}{lcccc}
\hline Hierarchical structure & Groups composition & \multicolumn{3}{c}{ Proportion of variance } \\
\cline { 3 - 5 } & & & Among populations $\left(\mathrm{F}_{\mathrm{ST}}\right)$ & Within populations \\
\hline Not structured & (1) All populations & - & $11.49 \%$ & $88.51 \%$ \\
& & & $(0.1149 ; \mathrm{p}=0.0000)$ & \\
& & Among groups & Among populations & Within populations \\
& & $\left(\mathrm{F}_{\mathrm{CT}}\right)$ & within groups $\left(\mathrm{F}_{\mathrm{SC}}\right)$ & $\left(\mathrm{F}_{\mathrm{ST}}\right)$ \\
Structured (historical data) & (1) (2) (3) & $4.82 \%$ & $7.84 \%$ & $87.34 \%$ \\
& & $(0.0482 ; \mathrm{p}=0.0000)$ & $(0.0824 ; \mathrm{p}=0.0000)$ & $(0.1266 ; \mathrm{p}=0.000)$ \\
\hline
\end{tabular}


tion could be attributed to differences between populations. This represents a moderate difference between populations and validates the $\mathrm{F}_{\mathrm{ST}}$ value detected for all populations. When populations were structured according to historical data, the AMOVA confirmed that most (87.34\%) of the total variation was caused by differences between individual animals within populations. The differentiation between populations within groups was higher than the differentiation between groups (Table 4), indicating that the UDB, naturalized or exotic purebred populations were highly differentiated.

The structuring seen in the phenogram confirmed the expected relationship of the populations (Figure 2). Igarashi et al. (2000) investigated these populations with protein markers and reported similar structuring. The grouping of the UDB populations with the exotic purebred populations can be explained by some crossbreeding (Igarashi et al., 2000). Native and exotic breeds, including the Anglo-Nubian, may influence UDB populations, especially the UDB-NE and UDB-CL populations (Machado et al., 2000).

The branching pattern within the three major groups also showed considerable similarity to the results described by Igarashi et al. (2000), the similarities being as follows: As expected, the UDB populations were grouped in the same branch since they indirectly belong to the same group; the MOX-CE and CAN-CE populations were grouped in a separate branch, either due to the fact that they are Brazilian naturalized breeds or due to a derivative process through the isolation of the local population (Igarashi et al., 2000). According to Silva Neto (1950) the Moxotó breed may have already been brought from Portugal to Brazil in a standardized form; A branch with the TOG, ALP and SAA exotic purebred populations occurred. In this branch, the TOG population was set apart in a single branch, while the ALP and SAA populations were closer, probably reflecting the same origin (Igarashi et al., 2000); and the exotic purebred AGN-P population was separated from the other populations. This fact can be explained because such a breed, unlike the others, does not have an essentially European origin, instead it is a European (English), Middle-Eastern (Nubian) and maybe Asian (Indian) synthetic goat breed (Jeffery, 1977). In contrast to Igarashi et al. (2000) and our PCA results, our AGN-M population was connected to the exotic purebreds via a single branch. However, $\mathrm{F}_{\mathrm{ST}}$ analysis confirmed the similarity of the AGN-M population to the UDB populations.

Finally, the phenogram presented a branch including three populations, the Canindé and Graúna populations from the state of Paraíba and, more separately, another Canindé population from the state of Rio Grande do Norte. The clustering of these populations can be easily explained by the fact that they are regarded as populations of Brazilian naturalized breeds (Igarashi et al., 2000). The CAN-PB and GRA-PB grouping reveals that the CAN-PB popula- tion is less similar to the genetically conserved CAN-CE population. In some locations there are problems related to the crossing of goats and, due to lack of information about standardized characteristics, some farmers are making crossings based only on coat color. Since the CAN-PB population also presents a black coat as GRA-PB, we believe that this process may be occurring between the GRA-PB and CAN-PB populations, explaining the similarity among these populations. This highlights the importance of an official government role in the conservation of local goat breeds.

All the analyses showed consistency and reliability, and reproduced the geographic and genetic reports of the population studied. They established the genetic structure of the populations in three major groups and showed that the populations in these groups were highly differentiated due to high inbreeding, indicating that the preservation of these breeds and the genetic diversity among them is extremely important.

\section{Acknowledgments}

We are grateful to Dr. Maria de Nazaré Klautau Guimarães Grisolia (Universidade de Brasília) and Silvia Ribeiro de Castro (EMBRAPA/CENARGEN) for providing samples from the CAN- PB, CAN-RN, MOX-PB and GRA-PB populations. Supports from EMBRAPA-CNP Caprinos, EMBRAPA-CENARGEN and the former Empresa de Pesquisa Agropecuária do Ceará, are also acknowledged. We also thank Elisabete Barreto Beira for technical assistance, and to FAPESP for providing a fellowship to MLSP Igarashi.

\section{References}

Araújo AM, Guimarães SEF, Machado TMM, Lopes PS, Pereira CS, Silva FLR, Rodrigues MT, Columbiano VS and Fonseca CG (2006) Genetic diversity between herds of Alpine and Saanen dairy goats and naturalized Brazilian Moxotó breed. Genet Mol Biol 29:67-74.

Barker JSF, Tan SG, Moore SS, Mukherjee TK, Matheson J-L and Selvaraj OS (2001) Genetic variation within and relationships among populations of Asian goats (Capra hircus). J Anim Breed Genet 118:213-233.

Baumung R, Simianer H and Hoffmann I (2004) Genetic diversity studies in farm animals - A survey. J Anim Breed Genet 121:361-373.

Excoffier L, Smouse P and Quattro J (1992) Analysis of molecular variance inferred from metric distances among DNA haplotypes: Application to human mitochondrial DNA restriction data. Genetics 13:1479-491.

Excoffier L, Laval G and Schneider S (2005) Arlequin (version 3.0) An Integrated Software Package for Population Genetics Data Analysis. Evolutionary Bioinformatics Online 1:47-50. http//cmpgunibech/software/arlequin3/.

Guo SW and Thompson EA (1992) Performing the exact test of Hardy-Weinberg proportion for multiple alleles. Biometrics 48:361-372. 
Hartl DL and Clark AG (1997) Principles of Population Genetics 3rd edition. Sinauer Associates, Sunderland, 481 pp.

Higuchi R (1989) Simple and rapid preparation of samples for PCR. In: Erlich HA (ed) PCR Technology. Stockton Press, New York, pp 31-38.

Igarashi MLSP, Machado TMM, Ferro JA and Contel EPB (2000) Structure and genetic relationship among Brazilian naturalized and imported goat breeds. Biochem Genet 38:353-365.

Jeffery HE (1977) A history of the Anglo-Nubian breed. Dairy Goat J March:40-49.

Kim KS, Yeo JS, Lee JW, Kim JW and Choi CB (2002) Genetic diversity of goats from Korea and China using microsatellite analysis. Asian-Australas J Anim Sci 15:461-465.

Laval G, Iannuccelli N, Legault C, Milan D, Groenen MA, Giuffra E, Andersson L, Nissen PH, Jorgensen CB, Beeckmann P, Geldermann H, Foulley J-L, Chevalet C and Ollivier L (2000) Genetic diversity of eleven European pig breeds. Genet Sel Evol 32:187-203.

Li M-H, Zhao S-H, Bian C, Wang H-S, Wei H, Liu B, Yu M, Fan B, Chen S-L, Zhu M-J, Li S-J, Xiong T-A and Li K (2002) Genetic relationship among twelve Chinese indigenous goat populations based on microsatellite analysis. Genet Sel Evol 34:729-744.

Luikart G, Biju-Duval MP, Ertugrul O, Yagdsuren Y, Maudet C and Taberlet $P$ (1999) Power of 22 microsatellite markers in fluorescent multiplexes for parentage testing in goats (Capra hircus). Anim Genet 30:431-438.

Machado TMM, Chakir M and Lauvergne JJ (2000) Genetic distances and taxonomic trees between goats of Ceará state (Brazil) and goats of the Mediterranean region (Europe and Africa). Genet Mol Biol 23:121-125.

Oliveira RR, Egito AA, Ribeiro MN, Paiva SR, Albuquerque MSM, Castro SR, Mariante AS and Adrião M (2005) Genetic characterization of the Moxotó goat breed using RAPD markers. Pesq Agropec Bras 40:233-239.

Raymond M and Rousset F (1995) Genepop (version 1.2) A Population Genetics Software for Exact Tests and Ecumenicism. J Hered 86:248-249.

Reynolds J, Weir BS and Cockerham CC (1983) Estimation of the coancestry coefficient basis for a short-term genetic distance. Genetics 105:767-779.
Saitbekova N, Gaillard C, Obexer-Ruff G and Dolf G (1999) Genetic diversity in Swiss goat breeds based on microsatellite analysis. Anim Genet 30:36-41.

Saitou N and Nei M (1987) The Neighbor-Joining method: A new method for reconstructing phylogenetic trees. Mol Biol Evol 4:406-425.

Santos R (1987) O Berro - Revista Brasileira de Caprinos e Ovinos 2:1-90.

Silva Neto JMR (1950) Em Torno da Origem do Caprino Nacional Moxotó. Associação dos Engenheiros Agrônomos do Nordeste (Publicação n. 3), Recife, 43 pp.

Weir BS and Cockerham CC (1984) Estimating F-statistics for the analysis of population structure. Evolution 38:1358-1370.

Wright S (1951) The genetical structure of populations. Ann Eugen 15:395-420.

Wright S (1978) Evolution and the Genetics of Population. Vol 4. Variability Within and Among Natural Populations. The University of Chicago Press, Chicago.

Yang L, Zhao SH, Li K, Peng ZZ and Montgomery GW (1999) Determination of genetic relationships among five indigenous Chinese goat breeds with six microsatellite markers. Anim Genet 30:452-455.

\section{Internet Resources}

FSTAT Software, http//www.unil.ch/izea/softwares/fstat.html.

FUNDAÇÃO IBGE. Pesquisa Pecuária Municipal (PPM), http// www.sidra.ibge.gov.br/ (February 10, 2006).

GDA Software, http//hydrodictyon.eeb.uconn.edu/people/plewis/ software.php.

PCAGEN Software, http://www2.unil.ch/popgen/softwares/ pcagen.htm.

PHYLIP Software, http//evolution.gs.washington.edu/phylip. html.

\section{Supplementary Material}

The following online material is available for this article:

Table S1.

This material is available as part of the online article from http:// www.scielo.br/gmb

Associate Editor: Luiz Lehmann Coutinho 
Table S1 - Allele Frequencies for the Polymorphic Loci for Each Goat population Sampled.

\begin{tabular}{|c|c|c|c|c|c|c|c|c|c|c|c|c|c|c|c|}
\hline $\mathrm{L}$ o c u s & 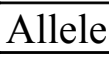 & & & & & & & & & & GRA & ALP & SAA & AGN-P & TOG \\
\hline \multirow[t]{26}{*}{ INRA011 } & 196 & 0.000 & 0.000 & 0.000 & 0.000 & 0.000 & 0.000 & 0.000 & 0.000 & 0.000 & 0.000 & 0.009 & 0.000 & 0.156 & 0.018 \\
\hline & 198 & 0.000 & 0.000 & 0.000 & 0.000 & 0.000 & 0.000 & 0.000 & 0.000 & 0.000 & 0.000 & 0.013 & 0.000 & 0.156 & 0.000 \\
\hline & 200 & 0.000 & 0.000 & 0.000 & 0.000 & 0.000 & 0.000 & 0.000 & 0.000 & 0.000 & 0.000 & 0.031 & 0.000 & 0.125 & 0.054 \\
\hline & 202 & 0.000 & 0.000 & 0.000 & 0.000 & 0.000 & 0.000 & 0.000 & 0.000 & 0.000 & 0.000 & 0.018 & 0.100 & 0.063 & 0.036 \\
\hline & 204 & 0.059 & 0.000 & 0.158 & 0.012 & 0.000 & 0.000 & 0.000 & 0.000 & 0.000 & 0.000 & 0.009 & 0.029 & 0.000 & 0.000 \\
\hline & 206 & 0.059 & 0.219 & 0.184 & 0.023 & 0.000 & 0.000 & 0.000 & 0.000 & 0.000 & 0.000 & 0.000 & 0.000 & 0.063 & 0.000 \\
\hline & 208 & 88 & 0.063 & 0.053 & 0.012 & 0.000 & 00 & 0.000 & 000 & 00 & 0.000 & 004 & 0.000 & 00 & 0.018 \\
\hline & 210 & 059 & 188 & 0.053 & 0.012 & 0.000 & 000 & 0.000 & 34 & 00 & 0.000 & 000 & 0.000 & 00 & 0.000 \\
\hline & 212 & 0.000 & 0.000 & 0.053 & 0.000 & 0.000 & .000 & 0.043 & 0.000 & .000 & 0.000 & 0.000 & 0.029 & 0.000 & 0.000 \\
\hline & 214 & 0.147 & 0.000 & 0.000 & 0.000 & 0.022 & 0.000 & 0.000 & 0.000 & 0.000 & 0.091 & 0.000 & 0.029 & 0.094 & 0.000 \\
\hline & 216 & 0.000 & 0.000 & 0.053 & 0.221 & 0.043 & 0.000 & 0.043 & 0.155 & 0.000 & 0.091 & 0.094 & 0.014 & 0.250 & 0.071 \\
\hline & 218 & 0.206 & 0.063 & 0.053 & 0.000 & 0.109 & 0.000 & 0.087 & 0.034 & 0.263 & 0.091 & 0.174 & 0.186 & 0.000 & 0.054 \\
\hline & 220 & 0.029 & 0.000 & 0.000 & 0.023 & 0.000 & 0.000 & 0.000 & 0.000 & & 0.000 & & 0.043 & & 0.000 \\
\hline & 222 & 0.088 & 0.156 & 0.289 & 0.593 & 0.022 & 0.125 & 0.239 & 0.017 & 0.053 & 0.045 & 0.045 & 0.000 & 0.000 & 0.018 \\
\hline & 224 & 6 & 0.219 & 0.079 & 0.093 & 0.435 & 50 & 3 & 8 & 21 & 0.364 & 27 & 0.000 & 31 & 0.018 \\
\hline & 226 & & 0.0 & 0.026 & 0.000 & 0.000 & 0 & & 0 & & 0.000 & & 0.057 & 00 & 0.125 \\
\hline & 228 & 0.000 & 0.063 & 0.000 & 0.000 & 0.109 & 0.000 & 0.000 & 0.052 & & 0.045 & 0.067 & 0.043 & 0.000 & 0.125 \\
\hline & 230 & 0.000 & 0.000 & 0.000 & 0.000 & 0.239 & 0.000 & 0.000 & 0.000 & 0.000 & 0.000 & 0.031 & 0.086 & 00 & 0.143 \\
\hline & 232 & 0.000 & 0.000 & 0.000 & 0.000 & 0.000 & 0.000 & 0.043 & 0.017 & 0.053 & 0.045 & 0.027 & 0.043 & 0.000 & 0.036 \\
\hline & 236 & 0.000 & 0.000 & 0.000 & 0.000 & 0.000 & 0.000 & 0.000 & 0.103 & & 0.000 & 0.027 & 0.014 & 0.000 & 0.000 \\
\hline & 238 & 0.000 & 0.000 & 0.000 & 0.012 & 0.022 & 0.000 & 0.000 & 0.034 & 0.000 & 0.000 & 0.013 & 0.000 & 0.000 & 0.071 \\
\hline & 240 & 0.000 & 0.000 & 0.000 & 0.000 & 0.000 & 0.000 & 0.000 & 0.155 & 0.079 & 0.091 & 0.009 & 0.100 & 0.000 & 0.071 \\
\hline & 242 & & & 0.000 & & 0.000 & & & & & 0.045 & 0.040 & 0.157 & 0.000 & 0.036 \\
\hline & 244 & 0.000 & 0.000 & 0.000 & 0.000 & 0.000 & 0.000 & & & 0.026 & 0.000 & 0.156 & 0.071 & 0.000 & 0.071 \\
\hline & 246 & & & 0.000 & 0.000 & 0.000 & & & & & 0.000 & & 0.000 & 0.063 & 0.018 \\
\hline & 250 & 0.000 & 0.000 & 0.000 & 0.000 & 0.000 & 0.000 & 0.000 & 0.034 & 0.000 & 0.091 & 0.049 & 0.000 & 0.000 & 0.018 \\
\hline \multirow[t]{3}{*}{ INRA040 } & 166 & 0.000 & 0.000 & 0.000 & 0.000 & 0.000 & 0.000 & 0.000 & 0.093 & 0.094 & 0.045 & 0.009 & 0.000 & 0.000 & 0.000 \\
\hline & 172 & 0.000 & 0.000 & 0.000 & 0.000 & 0.000 & 0.000 & 0.043 & 0.000 & 0.000 & 0.000 & 0.000 & 0.000 & 0.000 & 0.000 \\
\hline & 196 & 0.063 & 0.031 & 0.053 & 0.107 & 0.000 & 0.000 & 0.000 & 0.000 & 0.063 & 0.045 & 0.004 & 0.043 & 0.000 & 0.018 \\
\hline
\end{tabular}




\begin{tabular}{|c|c|c|c|c|c|c|c|c|c|c|c|c|c|c|c|}
\hline & 197 & 0.000 & 0.125 & 0.000 & 0.000 & 0.000 & 0.000 & 0.000 & 0.000 & 0.000 & 0.000 & 0.085 & 0.057 & 0.000 & 0.018 \\
\hline & 198 & 0.031 & 0.000 & 0.000 & 0.012 & 0.022 & 0.000 & 0.000 & 0.000 & 0.000 & 0.000 & 0.049 & 0.000 & 0.000 & 0.018 \\
\hline & 202 & 0.000 & 0.000 & 0.026 & 0.012 & 0.000 & 0.000 & 0.000 & 0.000 & 0.000 & 0.000 & 0.013 & 0.000 & 0.067 & 0.000 \\
\hline & 210 & 0.000 & 0.000 & 0.000 & 0.000 & 0.000 & 0.000 & 0.000 & 0.000 & 0.000 & 0.000 & 0.000 & 0.014 & 0.100 & 0.018 \\
\hline & 214 & 0.063 & 0.156 & 0.053 & 0.012 & 0.000 & 0.000 & 0.000 & 0.000 & 0.000 & 0.000 & 0.000 & 0.000 & 0.000 & 0.000 \\
\hline & 216 & 0.063 & 0.000 & 0.000 & 0.000 & 0.000 & 0.000 & 0.000 & 0.000 & 0.000 & 0.000 & 0.004 & 0.000 & 0.067 & 0.000 \\
\hline & 222 & 0.000 & 0.125 & 0.132 & 0.000 & 0.022 & 0.000 & 0.065 & 0.000 & 0.000 & 0.000 & 0.027 & 0.029 & 0.067 & 0.000 \\
\hline & 225 & 0.031 & 0.031 & 0.026 & 0.012 & 0.000 & 0.000 & 0.000 & 0.000 & 0.000 & 0.000 & 0.027 & 0.029 & 0.000 & 0.089 \\
\hline & 226 & 0.000 & 0.000 & 0.000 & 0.000 & 0.000 & 0.000 & 0.000 & 0.000 & 0.000 & 0.000 & 0.085 & 0.114 & 0.000 & 0.054 \\
\hline & 228 & 0.000 & 0.000 & 0.000 & 0.071 & 0.000 & 0.000 & 0.022 & 0.000 & 0.000 & 0.000 & 0.009 & 0.014 & 0.067 & 0.089 \\
\hline & 230 & 0.094 & 0.031 & 0.026 & 0.012 & 0.000 & 0.000 & 0.000 & 0.000 & 0.000 & 0.000 & 0.018 & 0.029 & 0.000 & 0.161 \\
\hline & 232 & 0.094 & 0.063 & 0.079 & 0.024 & 0.087 & 0.250 & 0.261 & 0.130 & 0.000 & 0.091 & 0.049 & 0.029 & 0.200 & 0.036 \\
\hline & 234 & 0.188 & 0.031 & 0.105 & 0.333 & 0.283 & 0.188 & 0.283 & 0.204 & 0.250 & 0.273 & 0.080 & 0.100 & 0.033 & 0.036 \\
\hline & 236 & 0.000 & 0.156 & 0.053 & 0.024 & 0.000 & 0.000 & 0.000 & 0.000 & 0.000 & 0.000 & 0.009 & 0.114 & 0.000 & 0.018 \\
\hline & 238 & 0.219 & 0.094 & 0.053 & 0.083 & 0.043 & 0.000 & 0.043 & 0.111 & 0.000 & 0.000 & 0.027 & 0.229 & 0.133 & 0.179 \\
\hline & 240 & 0.031 & 0.063 & 0.132 & 0.071 & 0.283 & 0.438 & 0.217 & 0.296 & 0.219 & 0.273 & 0.058 & 0.043 & 0.000 & 0.036 \\
\hline & 242 & 0.094 & 0.094 & 0.132 & 0.179 & 0.174 & 0.125 & 0.022 & 0.000 & 0.156 & 0.045 & 0.152 & 0.114 & 0.100 & 0.071 \\
\hline & 244 & 0.000 & 0.000 & 0.105 & 0.036 & 0.043 & 0.000 & 0.043 & 0.000 & 0.000 & 0.000 & 0.112 & 0.014 & 0.067 & 0.107 \\
\hline & 246 & 0.031 & 0.000 & 0.026 & 0.012 & 0.043 & 0.000 & 0.000 & 0.148 & 0.031 & 0.227 & 0.080 & 0.029 & 0.067 & 0.000 \\
\hline & 248 & 0.000 & 0.000 & 0.000 & 0.000 & 0.000 & 0.000 & 0.000 & 0.019 & 0.188 & 0.000 & 0.013 & 0.000 & 0.033 & 0.054 \\
\hline & 256 & 0.000 & 0.000 & 0.000 & 0.000 & 0.000 & 0.000 & 0.000 & 0.000 & 0.000 & 0.000 & 0.036 & 0.000 & 0.000 & 0.000 \\
\hline & 258 & 0.000 & 0.000 & 0.000 & 0.000 & 0.000 & 0.000 & 0.000 & 0.000 & 0.000 & 0.000 & 0.054 & 0.000 & 0.000 & 0.000 \\
\hline \multirow[t]{10}{*}{ BM3517 } & 100 & 0.000 & 0.000 & 0.025 & 0.000 & 0.000 & 0.000 & 0.000 & 0.065 & 0.143 & 0.000 & 0.017 & 0.000 & 0.067 & 0.018 \\
\hline & 103 & 0.118 & 0.000 & 0.000 & 0.023 & 0.000 & 0.000 & 0.022 & 0.000 & 0.000 & 0.111 & 0.009 & 0.000 & 0.000 & 0.018 \\
\hline & 107 & 0.059 & 0.219 & 0.075 & 0.070 & 0.182 & 0.188 & 0.261 & 0.130 & 0.179 & 0.333 & 0.248 & 0.500 & 0.633 & 0.143 \\
\hline & 110 & 0.000 & 0.000 & 0.000 & 0.047 & 0.045 & 0.000 & 0.000 & 0.022 & 0.143 & 0.056 & 0.052 & 0.182 & 0.033 & 0.143 \\
\hline & 111 & 0.088 & 0.031 & 0.075 & 0.035 & 0.068 & 0.313 & 0.196 & 0.196 & 0.071 & 0.111 & 0.052 & 0.076 & 0.067 & 0.196 \\
\hline & 113 & 0.000 & 0.000 & 0.150 & 0.093 & 0.023 & 0.000 & 0.000 & 0.000 & 0.107 & 0.000 & 0.035 & 0.000 & 0.000 & 0.071 \\
\hline & 115 & 0.471 & 0.188 & 0.300 & 0.477 & 0.045 & 0.000 & 0.000 & 0.043 & 0.000 & 0.000 & 0.404 & 0.076 & 0.100 & 0.036 \\
\hline & 117 & 0.000 & 0.000 & 0.025 & 0.047 & 0.114 & 0.000 & 0.065 & 0.043 & 0.071 & 0.000 & 0.000 & 0.000 & 0.000 & 0.018 \\
\hline & 119 & 0.059 & 0.000 & 0.000 & 0.023 & 0.068 & 0.000 & 0.043 & 0.087 & 0.071 & 0.111 & 0.004 & 0.015 & 0.000 & 0.036 \\
\hline & 121 & 0.059 & 0.125 & 0.075 & 0.070 & 0.341 & 0.500 & 0.304 & 0.130 & 0.107 & 0.111 & 0.026 & 0.045 & 0.000 & 0.018 \\
\hline
\end{tabular}




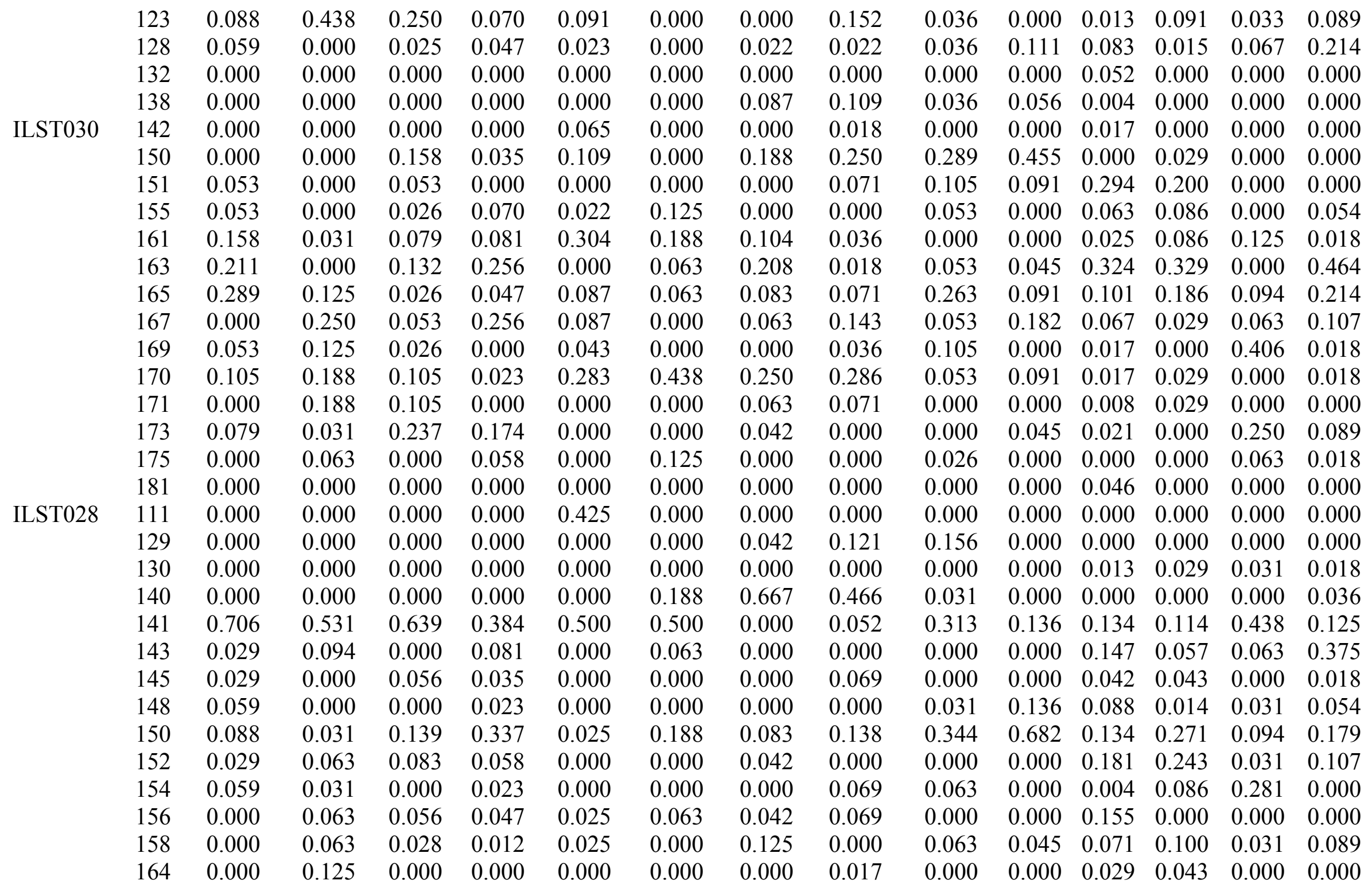




\begin{tabular}{|c|c|c|c|c|c|c|c|c|c|c|c|c|c|c|c|}
\hline \multirow[t]{17}{*}{ UWCA46 } & 97 & 0.000 & 0.000 & 0.000 & 0.000 & 0.022 & 0.000 & 0.000 & 0.000 & 0.000 & 0.000 & 0.000 & 0.000 & 0.000 & 0.000 \\
\hline & 99 & 0.000 & 0.000 & 0.000 & 0.000 & 0.609 & 0.438 & 0.000 & 0.000 & 0.000 & 0.000 & 0.000 & 0.000 & 0.000 & 0.000 \\
\hline & 110 & 0.000 & 0.000 & 0.000 & 0.000 & 0.283 & 0.313 & 0.000 & 0.000 & 0.000 & 0.000 & 0.000 & 0.000 & 0.000 & 0.000 \\
\hline & 113 & 0.000 & 0.000 & 0.000 & 0.000 & 0.000 & 0.000 & 0.042 & 0.000 & 0.000 & 0.000 & 0.000 & 0.129 & 0.000 & 0.000 \\
\hline & 114 & 0.206 & 0.250 & 0.079 & 0.047 & 0.043 & 0.125 & 0.125 & 0.018 & 0.029 & 0.000 & 0.000 & 0.000 & 0.000 & 0.000 \\
\hline & 115 & 0.000 & 0.063 & 0.000 & 0.023 & 0.000 & 0.000 & 0.083 & 0.000 & 0.059 & 0.000 & 0.004 & 0.000 & 0.000 & 0.000 \\
\hline & 117 & 0.324 & 0.313 & 0.368 & 0.128 & 0.000 & 0.000 & 0.188 & 0.339 & 0.176 & 0.273 & 0.214 & 0.129 & 0.094 & 0.268 \\
\hline & 118 & 0.088 & 0.094 & 0.289 & 0.000 & 0.000 & 0.063 & 0.042 & 0.089 & 0.118 & 0.091 & 0.021 & 0.029 & 0.000 & 0.054 \\
\hline & 119 & 0.029 & 0.000 & 0.000 & 0.442 & 0.000 & 0.063 & 0.188 & 0.143 & 0.147 & 0.000 & 0.000 & 0.000 & 0.000 & 0.000 \\
\hline & 122 & 0.088 & 0.031 & 0.000 & 0.081 & 0.022 & 0.000 & 0.083 & 0.000 & 0.000 & 0.000 & 0.008 & 0.043 & 0.031 & 0.125 \\
\hline & 124 & 0.000 & 0.094 & 0.158 & 0.000 & 0.000 & 0.000 & 0.042 & 0.000 & 0.000 & 0.045 & 0.063 & 0.200 & 0.188 & 0.054 \\
\hline & 125 & 0.059 & 0.000 & 0.000 & 0.000 & 0.000 & 0.000 & 0.042 & 0.000 & 0.000 & 0.000 & 0.029 & 0.000 & 0.031 & 0.000 \\
\hline & 126 & 0.206 & 0.031 & 0.053 & 0.186 & 0.000 & 0.000 & 0.021 & 0.036 & 0.029 & 0.136 & 0.084 & 0.157 & 0.125 & 0.196 \\
\hline & 127 & 0.000 & 0.063 & 0.053 & 0.081 & 0.022 & 0.000 & 0.146 & 0.000 & 0.029 & 0.000 & 0.164 & 0.229 & 0.031 & 0.304 \\
\hline & 130 & 0.000 & 0.063 & 0.000 & 0.012 & 0.000 & 0.000 & 0.000 & 0.000 & 0.029 & 0.000 & 0.412 & 0.086 & 0.469 & 0.000 \\
\hline & 136 & 0.000 & 0.000 & 0.000 & 0.000 & 0.000 & 0.000 & 0.000 & 0.304 & 0.176 & 0.364 & 0.000 & 0.000 & 0.000 & 0.000 \\
\hline & 140 & 0.000 & 0.000 & 0.000 & 0.000 & 0.000 & 0.000 & 0.000 & 0.071 & 0.206 & 0.091 & 0.000 & 0.000 & 0.031 & 0.000 \\
\hline \multirow[t]{9}{*}{ TEXAN02 } & 105 & 0.000 & 0.063 & 0.000 & 0.035 & 0.022 & 0.000 & 0.000 & 0.000 & 0.105 & 0.045 & 0.000 & 0.000 & 0.219 & 0.000 \\
\hline & 113 & 0.632 & 0.781 & 0.816 & 0.523 & 0.935 & 0.375 & 0.854 & 0.534 & 0.263 & 0.318 & 0.286 & 0.514 & 0.281 & 0.357 \\
\hline & 115 & 0.079 & 0.031 & 0.053 & 0.326 & 0.043 & 0.188 & 0.083 & 0.138 & 0.000 & 0.091 & 0.298 & 0.243 & 0.469 & 0.518 \\
\hline & 117 & 0.132 & 0.094 & 0.132 & 0.000 & 0.000 & 0.375 & 0.063 & 0.017 & 0.211 & 0.000 & 0.269 & 0.243 & 0.031 & 0.089 \\
\hline & 119 & 0.000 & 0.000 & 0.000 & 0.035 & 0.000 & 0.063 & 0.000 & 0.034 & 0.026 & 0.000 & 0.134 & 0.000 & 0.000 & 0.000 \\
\hline & 121 & 0.158 & 0.031 & 0.000 & 0.081 & 0.000 & 0.000 & 0.000 & 0.276 & 0.368 & 0.500 & 0.008 & 0.000 & 0.000 & 0.036 \\
\hline & 129 & 0.000 & 0.000 & 0.000 & 0.000 & 0.000 & 0.000 & 0.000 & 0.000 & 0.026 & 0.000 & 0.000 & 0.000 & 0.000 & 0.000 \\
\hline & 131 & 0.000 & 0.000 & 0.000 & 0.000 & 0.000 & 0.000 & 0.000 & 0.000 & 0.000 & 0.000 & 0.004 & 0.000 & 0.000 & 0.000 \\
\hline & 133 & 0.000 & 0.000 & 0.000 & 0.000 & 0.000 & 0.000 & 0.000 & 0.000 & 0.000 & 0.045 & 0.000 & 0.000 & 0.000 & 0.000 \\
\hline \multirow[t]{6}{*}{ ILST011 } & 262 & 0.000 & 0.000 & 0.000 & 0.000 & 0.023 & 0.000 & 0.042 & 0.000 & 0.000 & 0.000 & 0.004 & 0.000 & 0.000 & 0.000 \\
\hline & 268 & 0.000 & 0.000 & 0.000 & 0.000 & 0.000 & 0.000 & 0.000 & 0.000 & 0.000 & 0.000 & 0.030 & 0.000 & 0.000 & 0.179 \\
\hline & 270 & 0.536 & 0.267 & 0.294 & 0.209 & 0.545 & 0.375 & 0.604 & 0.442 & 0.353 & 0.375 & 0.205 & 0.214 & 0.063 & 0.000 \\
\hline & 272 & 0.000 & 0.067 & 0.000 & 0.012 & 0.045 & 0.000 & 0.000 & 0.000 & 0.000 & 0.000 & 0.205 & 0.114 & 0.063 & 0.375 \\
\hline & 276 & 0.000 & 0.000 & 0.000 & 0.000 & 0.091 & 0.000 & 0.000 & 0.096 & 0.088 & 0.000 & 0.000 & 0.000 & 0.000 & 0.000 \\
\hline & 278 & 0.250 & 0.100 & 0.294 & 0.488 & 0.023 & 0.000 & 0.063 & 0.038 & 0.412 & 0.188 & 0.397 & 0.514 & 0.469 & 0.286 \\
\hline
\end{tabular}




\begin{tabular}{|c|c|c|c|c|c|c|c|c|c|c|c|c|c|c|c|}
\hline & 280 & 0.214 & 0.567 & 0.412 & 0.186 & 0.227 & 0.625 & 0.250 & 0.288 & 0.000 & 0.313 & 0.111 & 0.100 & 0.406 & 0.125 \\
\hline & 282 & 0.000 & 0.000 & 0.000 & 0.105 & 0.045 & 0.000 & 0.042 & 0.000 & 0.000 & 0.063 & 0.047 & 0.057 & 0.000 & 0.036 \\
\hline & 284 & 0.000 & 0.000 & 0.000 & 0.000 & 0.000 & 0.000 & 0.000 & 0.135 & 0.147 & 0.063 & 0.000 & 0.000 & 0.000 & 0.000 \\
\hline \multirow{12}{*}{ INRA023 } & 191 & 0.000 & 0.000 & 0.000 & 0.012 & 0.000 & 0.000 & 0.000 & 0.000 & 0.053 & 0.000 & 0.021 & 0.000 & 0.000 & 0.107 \\
\hline & 195 & 0.000 & 0.000 & 0.000 & 0.000 & 0.043 & 0.000 & 0.000 & 0.000 & 0.000 & 0.000 & 0.013 & 0.029 & 0.094 & 0.018 \\
\hline & 197 & 0.563 & 0.917 & 0.947 & 0.384 & 0.674 & 0.750 & 0.826 & 0.411 & 0.526 & 0.450 & 0.218 & 0.271 & 0.031 & 0.214 \\
\hline & 199 & 0.219 & 0.000 & 0.053 & 0.140 & 0.239 & 0.125 & 0.087 & 0.143 & 0.000 & 0.100 & 0.357 & 0.229 & 0.063 & 0.125 \\
\hline & 201 & 0.031 & 0.000 & 0.000 & 0.291 & 0.000 & 0.000 & 0.000 & 0.089 & 0.053 & 0.050 & 0.000 & 0.043 & 0.156 & 0.036 \\
\hline & 203 & 0.094 & 0.083 & 0.000 & 0.081 & 0.000 & 0.000 & 0.022 & 0.000 & 0.000 & 0.000 & 0.004 & 0.000 & 0.344 & 0.000 \\
\hline & 205 & 0.000 & 0.000 & 0.000 & 0.000 & 0.022 & 0.063 & 0.000 & 0.089 & 0.132 & 0.200 & 0.000 & 0.057 & 0.125 & 0.089 \\
\hline & 207 & 0.031 & 0.000 & 0.000 & 0.023 & 0.000 & 0.000 & 0.043 & 0.000 & 0.000 & 0.050 & 0.034 & 0.000 & 0.000 & 0.071 \\
\hline & 211 & 0.000 & 0.000 & 0.000 & 0.012 & 0.000 & 0.000 & 0.000 & 0.000 & 0.000 & 0.000 & 0.059 & 0.043 & 0.031 & 0.071 \\
\hline & 213 & 0.063 & 0.000 & 0.000 & 0.058 & 0.022 & 0.063 & 0.022 & 0.232 & 0.132 & 0.050 & 0.206 & 0.314 & 0.063 & 0.268 \\
\hline & 215 & 0.000 & 0.000 & 0.000 & 0.000 & 0.000 & 0.000 & 0.000 & 0.000 & 0.053 & 0.050 & 0.059 & 0.014 & 0.063 & 0.000 \\
\hline & 217 & 0.000 & 0.000 & 0.000 & 0.000 & 0.000 & 0.000 & 0.000 & 0.036 & 0.053 & 0.050 & 0.029 & 0.000 & 0.031 & 0.000 \\
\hline \multirow[t]{17}{*}{ SRCRSP9 } & 106 & 0.000 & 0.000 & 0.000 & 0.012 & 0.239 & 0.250 & 0.021 & 0.052 & 0.000 & 0.000 & 0.000 & 0.000 & 0.000 & 0.000 \\
\hline & 109 & 0.000 & 0.000 & 0.000 & 0.000 & 0.152 & 0.188 & 0.042 & 0.017 & 0.000 & 0.000 & 0.000 & 0.000 & 0.000 & 0.000 \\
\hline & 110 & 0.028 & 0.000 & 0.000 & 0.000 & 0.000 & 0.000 & 0.000 & 0.000 & 0.000 & 0.000 & 0.000 & 0.129 & 0.000 & 0.125 \\
\hline & 111 & 0.000 & 0.000 & 0.000 & 0.000 & 0.022 & 0.125 & 0.063 & 0.190 & 0.158 & 0.091 & 0.000 & 0.014 & 0.000 & 0.000 \\
\hline & 115 & 0.000 & 0.000 & 0.000 & 0.070 & 0.000 & 0.000 & 0.000 & 0.017 & 0.000 & 0.000 & 0.059 & 0.000 & 0.031 & 0.000 \\
\hline & 117 & 0.000 & 0.000 & 0.025 & 0.000 & 0.000 & 0.000 & 0.000 & 0.017 & 0.000 & 0.045 & 0.050 & 0.000 & 0.406 & 0.000 \\
\hline & 118 & 0.056 & 0.000 & 0.050 & 0.000 & 0.000 & 0.125 & 0.000 & 0.000 & 0.000 & 0.045 & 0.063 & 0.014 & 0.000 & 0.036 \\
\hline & 120 & 0.000 & 0.000 & 0.025 & 0.023 & 0.239 & 0.000 & 0.042 & 0.017 & 0.053 & 0.000 & 0.000 & 0.014 & 0.063 & 0.018 \\
\hline & 122 & 0.000 & 0.031 & 0.125 & 0.012 & 0.087 & 0.125 & 0.042 & 0.017 & 0.026 & 0.045 & 0.008 & 0.000 & 0.031 & 0.000 \\
\hline & 123 & 0.139 & 0.094 & 0.000 & 0.000 & 0.000 & 0.000 & 0.000 & 0.000 & 0.000 & 0.000 & 0.029 & 0.157 & 0.375 & 0.339 \\
\hline & 124 & 0.194 & 0.063 & 0.350 & 0.047 & 0.000 & 0.000 & 0.125 & 0.052 & 0.289 & 0.318 & 0.105 & 0.171 & 0.000 & 0.107 \\
\hline & 125 & 0.000 & 0.031 & 0.000 & 0.000 & 0.261 & 0.125 & 0.000 & 0.000 & 0.000 & 0.000 & 0.092 & 0.086 & 0.000 & 0.071 \\
\hline & 126 & 0.111 & 0.406 & 0.300 & 0.430 & 0.000 & 0.000 & 0.125 & 0.138 & 0.053 & 0.227 & 0.143 & 0.143 & 0.031 & 0.143 \\
\hline & 128 & 0.250 & 0.063 & 0.050 & 0.163 & 0.000 & 0.000 & 0.104 & 0.207 & 0.026 & 0.045 & 0.290 & 0.029 & 0.000 & 0.089 \\
\hline & 129 & 0.000 & 0.000 & 0.025 & 0.035 & 0.000 & 0.000 & 0.063 & 0.034 & 0.105 & 0.091 & 0.038 & 0.086 & 0.000 & 0.036 \\
\hline & 135 & 0.194 & 0.219 & 0.025 & 0.174 & 0.000 & 0.000 & 0.083 & 0.000 & 0.053 & 0.045 & 0.029 & 0.043 & 0.063 & 0.000 \\
\hline & 136 & 0.000 & 0.000 & 0.000 & 0.000 & 0.000 & 0.000 & 0.000 & 0.000 & 0.000 & 0.000 & 0.029 & 0.029 & 0.000 & 0.000 \\
\hline
\end{tabular}




\begin{tabular}{|c|c|c|c|c|c|c|c|c|c|c|c|c|c|c|c|}
\hline \multirow{15}{*}{ MHCIIR } & 137 & 0.028 & 0.094 & 0.025 & 0.035 & 0.000 & 0.063 & 0.292 & 0.241 & 0.237 & 0.045 & 0.063 & 0.086 & 0.000 & 0.036 \\
\hline & 193 & 0.000 & 0.000 & 0.000 & 0.000 & 0.000 & 0.063 & 0.083 & 0.333 & 0.367 & 0.136 & 0.013 & 0.000 & 0.000 & 0.000 \\
\hline & 194 & 0.053 & 0.000 & 0.000 & 0.000 & 0.000 & 0.125 & 0.063 & 0.074 & 0.100 & 0.000 & 0.000 & 0.000 & 0.000 & 0.018 \\
\hline & 198 & 0.526 & 0.233 & 0.053 & 0.244 & 0.174 & 0.625 & 0.292 & 0.111 & 0.167 & 0.273 & 0.622 & 0.600 & 0.000 & 0.143 \\
\hline & 200 & 0.000 & 0.000 & 0.000 & 0.047 & 0.000 & 0.000 & 0.042 & 0.000 & 0.000 & 0.000 & 0.026 & 0.000 & 0.156 & 0.018 \\
\hline & 205 & 0.000 & 0.200 & 0.000 & 0.093 & 0.000 & 0.000 & 0.000 & 0.037 & 0.067 & 0.000 & 0.013 & 0.000 & 0.563 & 0.000 \\
\hline & 207 & 0.053 & 0.000 & 0.000 & 0.314 & 0.109 & 0.000 & 0.000 & 0.000 & 0.000 & 0.000 & 0.057 & 0.043 & 0.063 & 0.000 \\
\hline & 208 & 0.263 & 0.300 & 0.658 & 0.128 & 0.196 & 0.063 & 0.292 & 0.167 & 0.200 & 0.273 & 0.052 & 0.029 & 0.094 & 0.071 \\
\hline & 210 & 0.000 & 0.000 & 0.000 & 0.000 & 0.043 & 0.000 & 0.000 & 0.000 & 0.000 & 0.000 & 0.043 & 0.014 & 0.000 & 0.000 \\
\hline & 214 & 0.053 & 0.133 & 0.132 & 0.105 & 0.304 & 0.000 & 0.125 & 0.111 & 0.033 & 0.091 & 0.030 & 0.171 & 0.000 & 0.268 \\
\hline & 216 & 0.000 & 0.067 & 0.105 & 0.023 & 0.087 & 0.000 & 0.000 & 0.093 & 0.000 & 0.227 & 0.061 & 0.029 & 0.063 & 0.393 \\
\hline & 218 & 0.000 & 0.000 & 0.000 & 0.012 & 0.000 & 0.000 & 0.000 & 0.000 & 0.000 & 0.000 & 0.000 & 0.071 & 0.063 & 0.036 \\
\hline & 224 & 0.000 & 0.000 & 0.000 & 0.012 & 0.022 & 0.125 & 0.063 & 0.019 & 0.000 & 0.000 & 0.004 & 0.000 & 0.000 & 0.000 \\
\hline & 225 & 0.053 & 0.067 & 0.053 & 0.023 & 0.022 & 0.000 & 0.042 & 0.037 & 0.067 & 0.000 & 0.009 & 0.000 & 0.000 & 0.054 \\
\hline & 228 & 0.000 & 0.000 & 0.000 & 0.000 & 0.043 & 0.000 & 0.000 & 0.019 & 0.000 & 0.000 & 0.070 & 0.043 & 0.000 & 0.000 \\
\hline \multirow[t]{17}{*}{ INRA006 } & 95 & 0.053 & 0.000 & 0.075 & 0.000 & 0.217 & 0.125 & 0.104 & 0.000 & 0.528 & 0.091 & 0.004 & 0.000 & 0.000 & 0.000 \\
\hline & 103 & 0.000 & 0.000 & 0.000 & 0.198 & 0.000 & 0.000 & 0.000 & 0.000 & 0.000 & 0.045 & 0.017 & 0.000 & 0.000 & 0.018 \\
\hline & 105 & 0.026 & 0.031 & 0.125 & 0.058 & 0.043 & 0.000 & 0.000 & 0.034 & 0.000 & 0.000 & 0.029 & 0.000 & 0.375 & 0.000 \\
\hline & 107 & 0.263 & 0.188 & 0.025 & 0.419 & 0.000 & 0.000 & 0.042 & 0.121 & 0.000 & 0.000 & 0.008 & 0.014 & 0.031 & 0.125 \\
\hline & 108 & 0.000 & 0.000 & 0.000 & 0.012 & 0.000 & 0.000 & 0.000 & 0.000 & 0.000 & 0.000 & 0.050 & 0.071 & 0.094 & 0.286 \\
\hline & 109 & 0.368 & 0.156 & 0.300 & 0.070 & 0.370 & 0.375 & 0.125 & 0.362 & 0.028 & 0.136 & 0.084 & 0.057 & 0.000 & 0.125 \\
\hline & 111 & 0.000 & 0.000 & 0.075 & 0.023 & 0.065 & 0.000 & 0.000 & 0.017 & 0.000 & 0.000 & 0.013 & 0.000 & 0.063 & 0.000 \\
\hline & 113 & 0.026 & 0.063 & 0.075 & 0.012 & 0.000 & 0.000 & 0.083 & 0.121 & 0.139 & 0.318 & 0.042 & 0.086 & 0.063 & 0.000 \\
\hline & 114 & 0.000 & 0.000 & 0.000 & 0.070 & 0.000 & 0.000 & 0.000 & 0.000 & 0.000 & 0.000 & 0.092 & 0.286 & 0.000 & 0.071 \\
\hline & 115 & 0.132 & 0.188 & 0.150 & 0.058 & 0.065 & 0.000 & 0.063 & 0.017 & 0.000 & 0.091 & 0.256 & 0.043 & 0.063 & 0.000 \\
\hline & 116 & 0.000 & 0.000 & 0.000 & 0.000 & 0.000 & 0.250 & 0.000 & 0.000 & 0.000 & 0.000 & 0.067 & 0.171 & 0.063 & 0.071 \\
\hline & 117 & 0.026 & 0.188 & 0.050 & 0.047 & 0.000 & 0.063 & 0.042 & 0.000 & 0.028 & 0.091 & 0.181 & 0.057 & 0.063 & 0.214 \\
\hline & 119 & 0.000 & 0.188 & 0.075 & 0.012 & 0.000 & 0.000 & 0.104 & 0.086 & 0.167 & 0.136 & 0.063 & 0.186 & 0.188 & 0.036 \\
\hline & 121 & 0.105 & 0.000 & 0.000 & 0.012 & 0.065 & 0.188 & 0.188 & 0.052 & 0.000 & 0.091 & 0.050 & 0.029 & 0.000 & 0.018 \\
\hline & 123 & 0.000 & 0.000 & 0.050 & 0.012 & 0.000 & 0.000 & 0.021 & 0.017 & 0.000 & 0.000 & 0.021 & 0.000 & 0.000 & 0.000 \\
\hline & 125 & 0.000 & 0.000 & 0.000 & 0.000 & 0.000 & 0.000 & 0.021 & 0.103 & 0.056 & 0.000 & 0.008 & 0.000 & 0.000 & 0.036 \\
\hline & 127 & 0.000 & 0.000 & 0.000 & 0.000 & 0.000 & 0.000 & 0.146 & 0.034 & 0.000 & 0.000 & 0.000 & 0.000 & 0.000 & 0.000 \\
\hline
\end{tabular}




\begin{tabular}{|c|c|c|c|c|c|c|c|c|c|c|c|c|c|c|c|}
\hline \multirow{14}{*}{ IDVGA37 } & 135 & 0.000 & 0.000 & 0.000 & 0.000 & 0.152 & 0.000 & 0.042 & 0.017 & 0.028 & 0.000 & 0.008 & 0.000 & 0.000 & 0.000 \\
\hline & 137 & 0.000 & 0.000 & 0.000 & 0.000 & 0.022 & 0.000 & 0.021 & 0.017 & 0.028 & 0.000 & 0.004 & 0.000 & 0.000 & 0.000 \\
\hline & 192 & 0.000 & 0.000 & 0.000 & 0.000 & 0.000 & 0.000 & 0.238 & 0.000 & 0.000 & 0.045 & 0.141 & 0.014 & 0.000 & 0.000 \\
\hline & 194 & 0.000 & 0.000 & 0.025 & 0.012 & 0.043 & 0.000 & 0.000 & 0.017 & 0.132 & 0.091 & 0.021 & 0.000 & 0.000 & 0.000 \\
\hline & 196 & 0.000 & 0.000 & 0.000 & 0.000 & 0.196 & 0.063 & 0.048 & 0.017 & 0.000 & 0.000 & 0.000 & 0.000 & 0.000 & 0.000 \\
\hline & 198 & 0.000 & 0.125 & 0.050 & 0.073 & 0.326 & 0.125 & 0.024 & 0.224 & 0.158 & 0.182 & 0.043 & 0.014 & 0.031 & 0.036 \\
\hline & 200 & 0.026 & 0.156 & 0.275 & 0.000 & 0.000 & 0.000 & 0.000 & 0.138 & 0.132 & 0.000 & 0.085 & 0.114 & 0.281 & 0.286 \\
\hline & 202 & 0.132 & 0.000 & 0.000 & 0.037 & 0.000 & 0.000 & 0.119 & 0.017 & 0.079 & 0.045 & 0.073 & 0.243 & 0.219 & 0.089 \\
\hline & 204 & 0.105 & 0.125 & 0.050 & 0.012 & 0.022 & 0.125 & 0.167 & 0.138 & 0.316 & 0.227 & 0.021 & 0.157 & 0.031 & 0.089 \\
\hline & 206 & 0.132 & 0.000 & 0.125 & 0.061 & 0.043 & 0.000 & 0.071 & 0.086 & 0.053 & 0.045 & 0.107 & 0.157 & 0.000 & 0.286 \\
\hline & 208 & 0.158 & 0.156 & 0.050 & 0.341 & 0.043 & 0.188 & 0.071 & 0.103 & 0.026 & 0.182 & 0.338 & 0.286 & 0.250 & 0.161 \\
\hline & 210 & 0.132 & 0.281 & 0.350 & 0.329 & 0.239 & 0.438 & 0.143 & 0.190 & 0.000 & 0.091 & 0.056 & 0.000 & 0.188 & 0.054 \\
\hline & 212 & 0.026 & 0.000 & 0.050 & 0.024 & 0.000 & 0.000 & 0.048 & 0.017 & 0.026 & 0.000 & 0.090 & 0.000 & 0.000 & 0.000 \\
\hline & 216 & 0.289 & 0.156 & 0.025 & 0.110 & 0.087 & 0.063 & 0.071 & 0.052 & 0.079 & 0.091 & 0.026 & 0.014 & 0.000 & 0.000 \\
\hline
\end{tabular}

